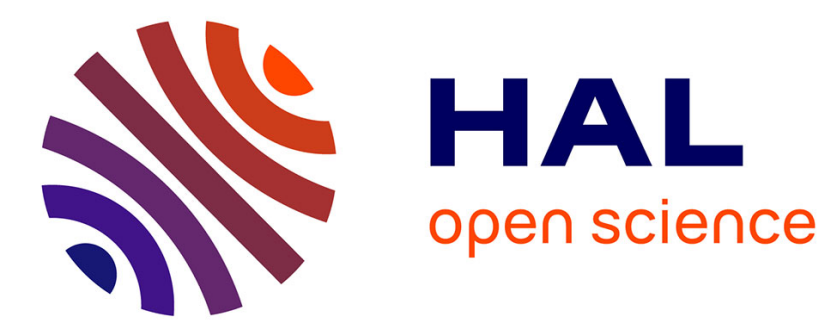

\title{
Assessment of Inorganic Chemical Composition of PM2.5 Aerosols in Tiaret-city, Algeria
}

Naceur Khadidja, Maatoug Mohamed, Belarbi Hbib, Serge Bresson, Stefan Henfling

\section{> To cite this version:}

Naceur Khadidja, Maatoug Mohamed, Belarbi Hbib, Serge Bresson, Stefan Henfling. Assessment of Inorganic Chemical Composition of PM2.5 Aerosols in Tiaret-city, Algeria. Natural Ressources Conservation and Advances for Sustainability, 2021, 10.1016/B978-0-12-822976-7.00005- . hal-03524970

\section{HAL Id: hal-03524970 \\ https://hal.science/hal-03524970}

Submitted on 13 Jan 2022

HAL is a multi-disciplinary open access archive for the deposit and dissemination of scientific research documents, whether they are published or not. The documents may come from teaching and research institutions in France or abroad, or from public or private research centers.
L'archive ouverte pluridisciplinaire HAL, est destinée au dépôt et à la diffusion de documents scientifiques de niveau recherche, publiés ou non, émanant des établissements d'enseignement et de recherche français ou étrangers, des laboratoires publics ou privés. 


\title{
Assessment of Inorganic Chemical Composition of PM2.5 Aerosols in Tiaret-city, Algeria
}

\author{
Naceur Khadidja ${ }^{a^{*}}$, Maatoug Mohamed ${ }^{a}$, Belarbi Hbib ${ }^{b}$, Serge Bresson ${ }^{c}$ \\ and Stefan Henfling ${ }^{d}$ \\ DOI: doi.org/10.1016/B978-0-12-822976-7.00005- \\ 3
}

\begin{abstract}
The objective of this work is to determine and quantify the inorganic compounds of $\mathrm{PM}_{2.5}$ aerosols; collected using a two-stage Dekati® PM10 impactor; in educational establishments in Tiaret-city "Algeria". It also aimed to follow the dispersion of these particles in sites near the forest, urban fabric and urban sites exposed to dense road traffic, as well as to determine the source of this type of pollution. 23 primary schools were chosen as sampling sites in Tiaret city. The collection of $\mathrm{PM}_{2.5}$ was carried out in the winter and summer period. The spectroscopic analysis carried out by FTiR-ATR shows that the sulfate ions recorded their maximum in the summer period than in the winter, as well as the nitrate and ammonium ions which do not show a large seasonal difference. The dominant species in urban areas are $\mathrm{NO}_{3}^{-}, \mathrm{SO}_{4}^{-2}$ which due to the presence of a very important source of $\mathrm{NOx}$ and $\mathrm{SO} 2$ which, by gas-particle conversion, transform into nitrate and sulfate ions respectively. These species present a lower proportion in sites close to the forest. However, the same order of abundance of these ions exists in the two sampling periods. The main sources of NOx in urban sites are combustion phenomena linked in particular to the transport system, which is characterized by very dense traffic in the city's agglomeration.
\end{abstract}

Keywords: Air pollution; PM 2.5 Aerosols; Road traffic; FTiR-ATR spectroscopy; Schools; Tiaret city.

\section{INTRODUCTION}

In recent decades, air quality has given rise to serious concerns in the face of rapid economic and industrial development in many countries around the world. Currently, suspended particles (PM) are universally recognized as the main pollutant in the atmosphere [1].

In urban areas, PM mainly comes from human activities. The automotive transport sector is one of the main responsible for their emission into the air, the latter contributing to the respective emission of $13 \%$ of $\mathrm{PM}_{2.5}$, with particles of aerodynamic diameter less than $2.5 \mu \mathrm{m}$ [2]. Numerous studies on the toxicological effects of suspended particles have reported that exposure to fine particles $\left(\mathrm{PM}_{2.5}\right)$ constitutes a risk factor for human health.

Our work consisted in determining the inorganic chemical composition of $\mathrm{PM}_{2.5}$, by estimating the different sources of emission of these particles inTiaret city, to provide local authorities with better knowledge of the sources on which we can act to decrease particle levels.

\footnotetext{
${ }^{a}$ Laboratory of Agro-biotechnology and Nutrition in Semi-arid Areas. Faculty of Natural Sciences and Life, University of Tiaret, Tiaret BP 78 Zaaroura, Tiaret, Algeria.

${ }^{b}$ Synthesis and catalysis Laboratory, Ibn Khaldoun Universiy , BP78 RP 14000 Tiaret- Algeria.

' Laboratory of Complex System Physics, Picardie Jules Verne Universiy, 33 rue St. Leu, 80039 Amiens cedex, France.

${ }^{d}$ Institue of Inorganic Chemistry Johannisallee 29, D-04103 Leipzig- Germany.

${ }^{*}$ Corresponding author: E-mail: khadidja366@gmail.com;
} 


\section{MATERIALS AND METHODS}

\subsection{Study Zone}

The study was carried out in Tiaret city. It is located in the North-West of Algeria, between the Tellian chain in the North and the Atlassian chain in the South, at an altitude of $980 \mathrm{~m}$ on average (Fig. 1). The climate is semi-arid Mediterranean with an average annual rainfall of $400 \mathrm{~mm} /$ year. The predominant winds come from the West and the North-West, their average speeds vary from 3 to $4 \mathrm{~m} / \mathrm{s}$.

This city had more than $200 \mathrm{~km}$ of the urban road network, its vehicle fleet are made up of 156,952 vehicles of all types, and $71.33 \%$ of gasoline cars, and $26 \%$ diesel. This park is very heterogeneous (private or a utility vehicle, gasoline or diesel, recent or old, etc.). In total, new cars (0 to 5 years old) represent $12 \%$ of the park. On the other hand, cars over 10 years old represent $75 \%$. However, older vehicles are the most polluting [3].

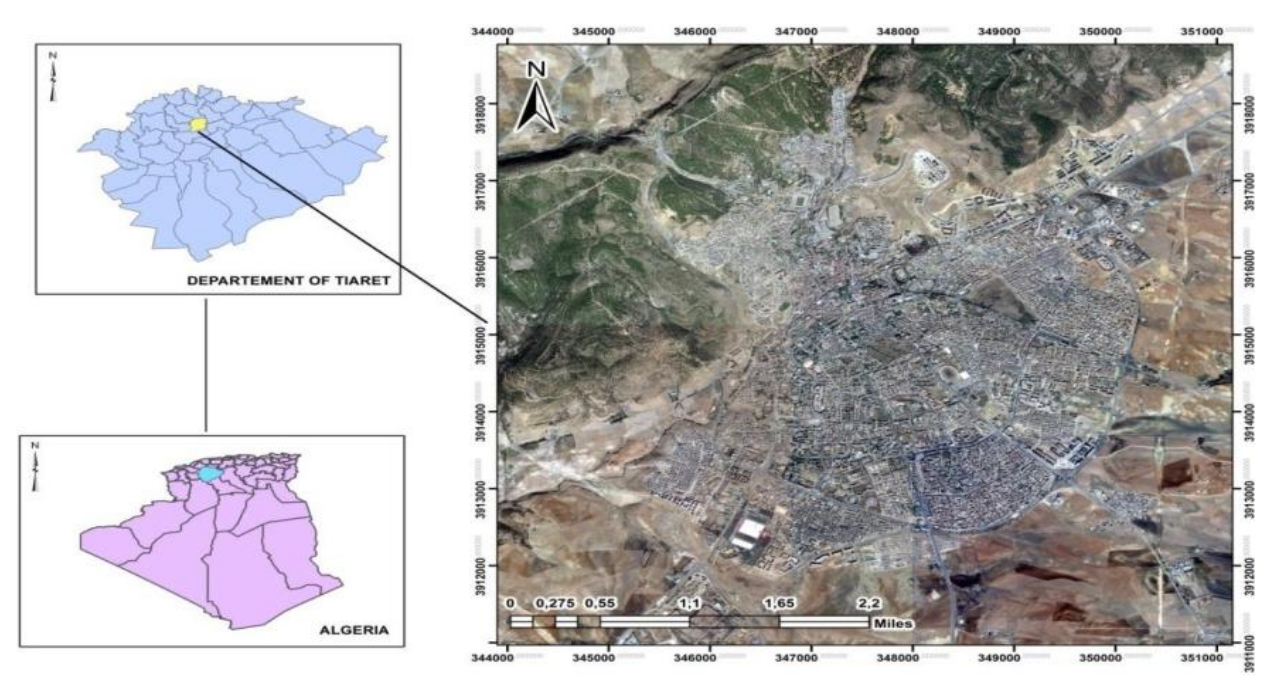

Fig. 1. Location of the study area [4]

\subsection{Selection of Sites}

The purpose of this study is to collect $\mathrm{PM}_{2.5}$ in primary schools in the city of Tiaret by a two-stage Dekatiß PM10 impactor (ISO23210, www.dekati.com, 2017), and to determine its chemical inorganic composition. Overall, 23 primary schools were chosen in these three axes (sites located near the forest (green circle), urban sites (yellow circle) and urban sites exposed to dense road traffic (red circle)) (Fig. 2).

Collecting the $\mathrm{PM}_{2.5}$ involves placing the Dekati impactor in the middle of the schoolyard with one meter high, in order to remove any source of contamination from the ground. The collection time is 30 minutes, with six samples/ a day/ a school. A total of 276 samples were collected, during eight months of sampling.

\subsection{FTiR-ATR Spectroscopy Analysis}

The particles sampled are detected by back scattered an electron image analysis (chemical contrast) after a calibration of the microscope. The Cartesian coordinates of each detected particle are stored and an X microanalysis is performed automatically for each particle. The counting time per a particle is of the order of 2 to $4 \mathrm{~s}$. The elements (Ammonium NH4+, Phosphates PO4-3, and Nitrate NO-3) were also analyzed by UV-visible spectroscopy. 


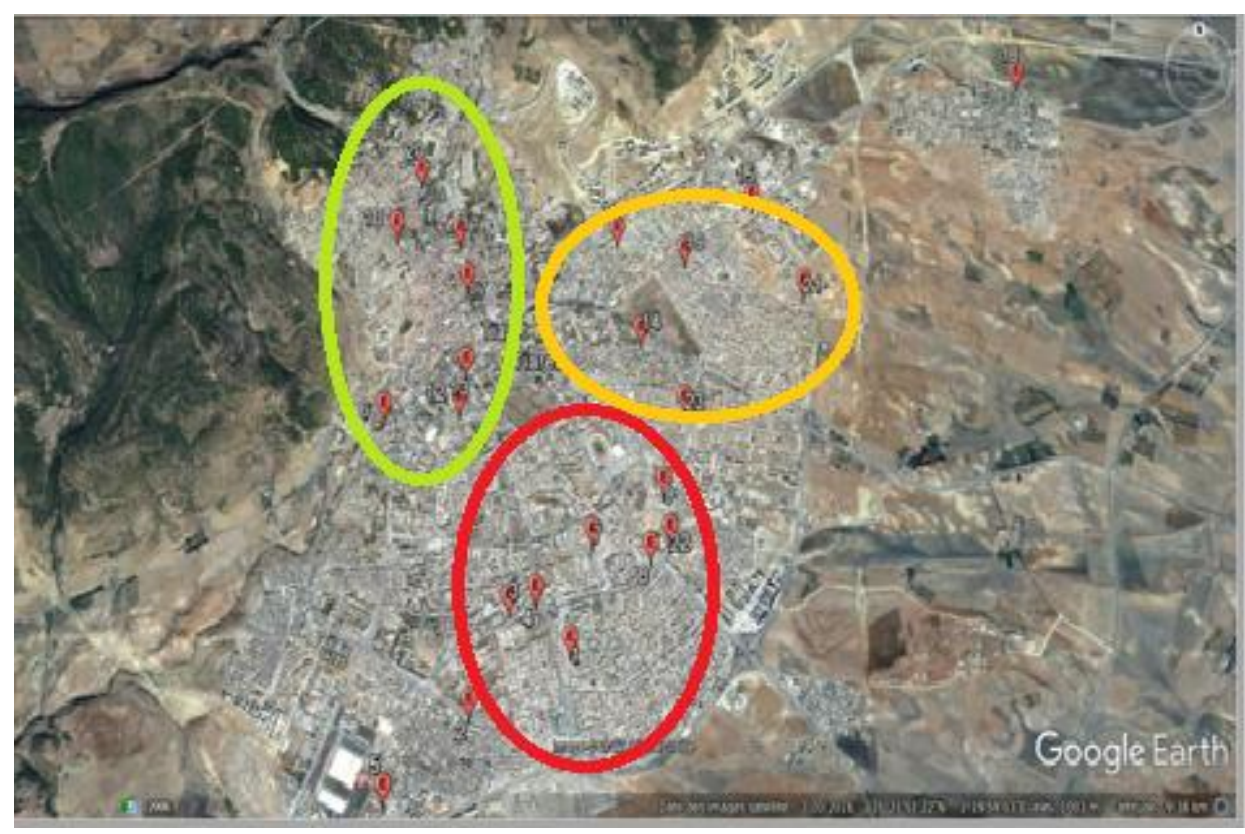

Fig. 2. Location of sampling sites (Google Earth, 2017)

\section{RESULTS AND DISCUSSION}

\subsection{Spectroscopic Analysis Results}

The results found by this analysis are illustrated in Fig. 3 which presents the FTiR-ATR spectra, of different samples taken

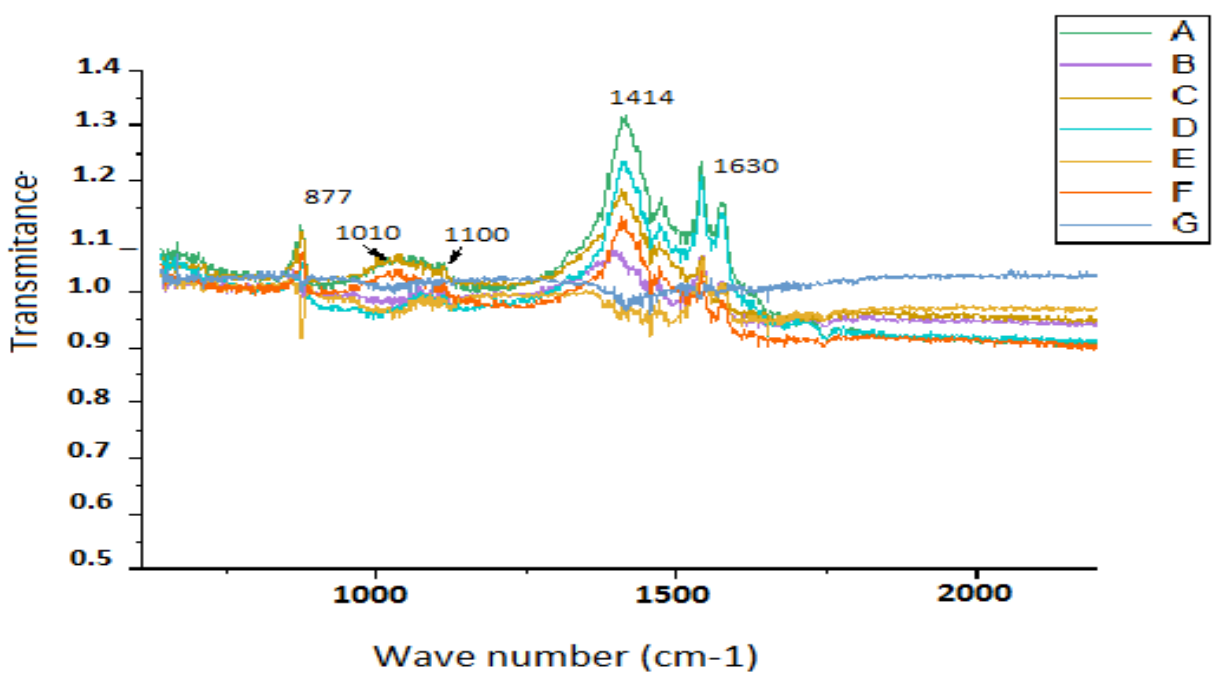

Fig. 3. Sample spectra of PM2.5 analyzed by FTiR spectroscopy

Légende:

A: Spectrum of sample taken from school $N^{\circ} 04$ (class 3), B: Spectrum of sample taken from school $N \circ 18$ (class 1 )

C: Spectrum of sample taken in school $N^{\circ} 13$ (class 2), D: Spectrum of sample taken in school $N^{\circ} 01$ (class 3)

E: Spectrum of sample taken in school $N^{\circ} 20$ (class 1), F: Spectrum of sample taken in school $N^{\circ} 23$ (class 2)

G: Spectrum of sample taken from school No. 20 (class 1)

The peaks had found in the spectra of samples taken from sites exposed to heavy traffic and urban samples are similar to each other. This suggests that the structural and functional groups of PM2.5 
samples show many similarities. The figure shows that ammonium and these derivatives show maximum concentrations during sampling at $1414 \mathrm{~cm}-1$ in the different samples. Most of the PM2.5 samples peak at $615 \mathrm{~cm}-1$, which exhibits the element of SO4-2, revealing that the sulfate ion is an important component of the collected PM2.5 particles. The peak reported at $1450 \mathrm{~cm}-1$, which characterizes solid samples, can be attributed to functional organic groups such as aliphatic carbon $(\mathrm{CH}-3)$. This finding shows a great consistency in the functional properties of PM2.5. However, most cations and anions are secondary pollutants that formed in the atmosphere from primary pollutants. The conversion of secondary pollutants depends on the concentrations of the primary pollutants (precursors) and meteorological parameters, such as a temperature and a solar radiation. Therefore, the positive association probably shows that the meteorological parameters affect both ions (NO3 and SO2). Nitrates and ammonium show different sulfate profiles during the secondary pollution process, the formation of nitrates is more intense than that of sulfates shows a significant improvement during the rapidly forming a pollution episode [2].

We have observed the presence of SO4-2, NO3-, SiO4-2, $\mathrm{CO} 3-$ and $\mathrm{NH} 4+$ cations with higher concentrations in the collected particles. This also showed that dust storms are characterized by an enrichment in a sio4-2 and a caco3.

\subsubsection{Winter period}

The most abundant anions are sulfates, nitrates at 825,1356 and $1410 \mathrm{~cm}^{-1}\left(\mathrm{NO}_{3}{ }^{-}\right)$and chlorides. The most abundant cations are ammonium and these derivatives at $1414 \mathrm{~cm}^{-1}\left(\mathrm{NH}_{4}{ }^{+},\left(\mathrm{NH}_{4}\right)_{2} \mathrm{SO}_{4}\right)$ and sulfate [5]. These ions mainly come from the automotive source. Most often, these compounds are very soluble in water (in the case of sulfate), and promote the capture of atmospheric water and therefore the formation of clouds. There are also insoluble or less soluble elements such as aluminosilicates, and transition metals such as iron, mainly from the terrigenous source (Fig.4)

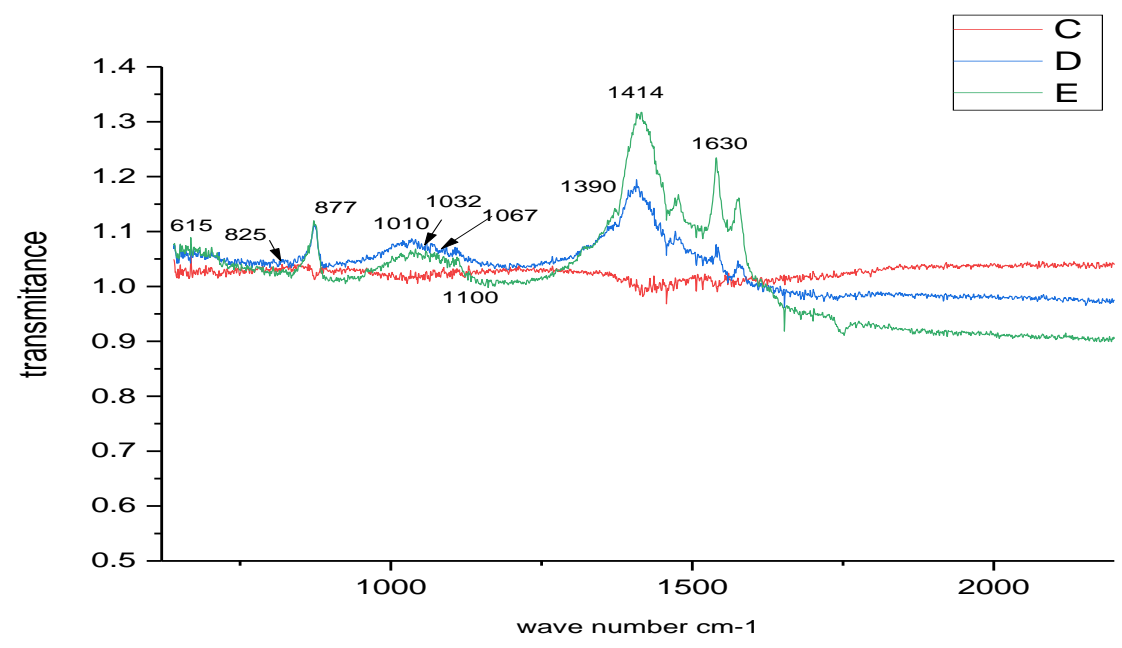

Fig. 4. Sample spectra of PM2.5 analyzed by FTiR spectroscopy during the winter period Légende:

C: Spectrum of sample taken from school No. 20 (class 1)

$D$ : Spectrum of sample taken from school $N \circ 12$ (class 2)

$E$ : Spectrum of sample taken from school $N^{\circ} 2$ (class 3 )

The peak recorded at $1010,1114 \mathrm{~cm}^{-1}$ is probably related to the Si-O group [6]. Thus, $\mathrm{OH}$ radicals can oxidize $\mathrm{SO}_{2}$ and $\mathrm{NO}_{2}$, respectively into sulfuric acid $\left(\mathrm{H}_{2} \mathrm{SO}_{4}\right)$ and nitric acid $\left(\mathrm{HNO}_{3}\right)$ [7]. These ions found recorded high values in the 3rd class which group together urban sites heavily polluted by road traffic than the other classes.

Sulfates are often associated with $\mathrm{NH} 4+$ cations $(80 \%)$, as the ionic balance is in a favor of anions, there is a deficit of a positive charge, compensated by the contribution of $\mathrm{H}+$ ions. This phenomenon explains why the aerosol and therefore the rain or snow has formed around the aerosol after water vapor capture always has an acidic $\mathrm{pH}$. The $\mathrm{pH}$ is often around 5 . It can drop to 4 for certain types of snow. 


\subsubsection{Summertime}

The notable peak at $1630 \mathrm{~cm}^{-1}$ is attributed to the aromatic bond $\mathrm{C}=\mathrm{C}$. We record a vibration of a large peak at $1390 \mathrm{~cm}^{-1}$, which cannot be discerned in any of the potential source spectra (Fig. 5), It has been ignored by some studies, and by others [8]. it is attributed to compounds of $\mathrm{NH}_{4} \mathrm{NO}_{3}$. It is on behalf of the secondary particle which could be produced in photochemical processes, and exhibits a high concentration of secondary particles. Indeed, these results led to the conclusion that the secondary aerosol concentrations are very high during fog events in winter. However, the intensity of this peak is very different from that of the summer $\mathrm{PM}_{2.5}$ samples. Additionally, all $\mathrm{PM}_{2.5}$ samples have a broad peak at $1080 \mathrm{~cm}^{-1}$. Some authors have linked this peak to vibrations only from the C-O bond or 60 polysaccharides, but others believe that there is a strong overlap with the sulfate ion peak at $1090 \mathrm{~cm}^{-1}$.

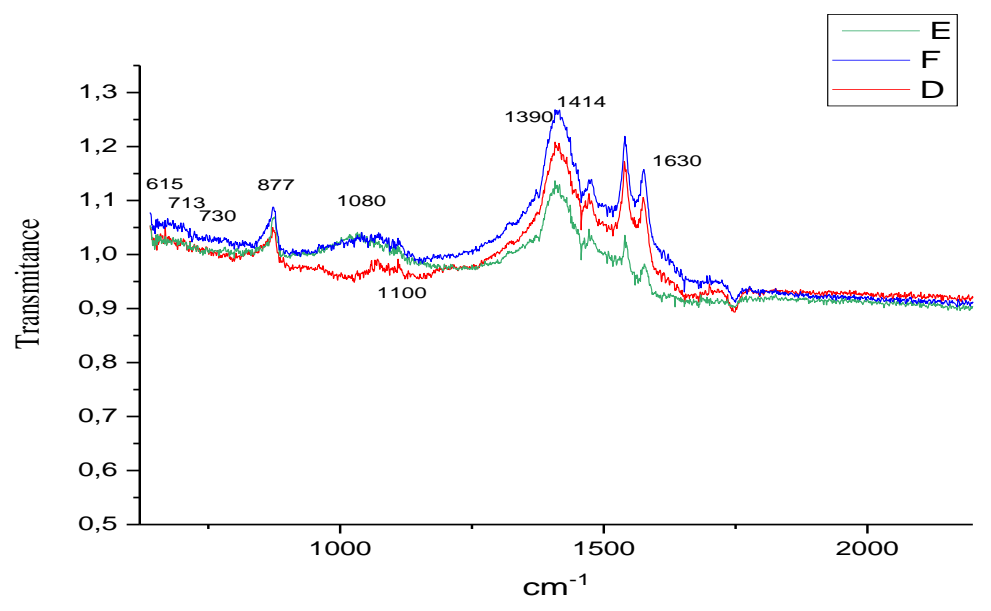

Fig. 5. Samples of PM 2.5 analyzed by FTiR-ATR during the summer period

Légende:

E: Spectrum of sample taken from school No. 20 (class 1);

D: Spectrum of sample taken from School No. 15 (class 2);

F: Spectrum of sample taken in school No. 2 (class 3).

In the $\mathrm{PM}_{2.5}$ samples analyzed, we observed typical vibration frequencies of the ions at $1414 \mathrm{~cm}^{-1}$ $\left(\mathrm{NH}_{4}^{+}\right) ; 825$ and $1356 \mathrm{~cm}^{-1}\left(\mathrm{NO}_{3}^{-}\right)$; and at 713,730 and $\left.877 \mathrm{~cm}^{-1} \mathrm{CO}_{3}^{-2}\right)$.

The presence of the compounds of $\left(\mathrm{NH}_{4}\right) 2 \mathrm{SO}_{4}$ and $\mathrm{NH}_{4} \mathrm{NO}_{3}$ is confirmed by the spectra also illustrated in Fig.5. Another peak was recorded at 615 and $1100 \mathrm{~cm}^{-1}\left(\mathrm{SO}_{4}^{-2}\right.$ group) [8]. The peak of $1100 \mathrm{~cm}^{-1}$ being attributed to the asymmetric stretching vibration of the sulfate ion. Ammonium, displayed a maximum concentration during the sampling days of this period, due to the high temperature and dry soil in the schoolyard. The main known reactions are photochemical oxidation by $\mathrm{OH}^{\circ}$ and $\mathrm{NO}^{\circ}$ radicals which lead to Nitro HAP3 [9]. These compounds are even more carcinogenic than the parent PAHs, but the concentrations generally do not exceed $0.1 \mathrm{ng} / \mathrm{m} 3$, except during strong episodes of photochemical pollution.

\subsubsection{Seasonal variations}

Seasonal variations in cation and anion concentrations show that the nitrate concentration was higher during summer sampling and halved during winter. Due to the low rate of photochemical oxidation of organic material to produce $\mathrm{OH}$; a radical responsible for the formation of $\mathrm{HNO}_{3}$ via (R12) [10]. The ion concentrations of the sulfates followed a pattern similar to that of the ions of the nitrates. The photochemical oxidation of SO2 becomes active in summer (solar radiation and high temperatures) to produce SO2-4 [11]. The concentration of ammonium ions which had the highest percentage in these fine particles showed relatively higher levels in summer. The variation of these ions is well correlated with the sulfate ions which recorded an increase in summer, due to the improvement in the rate of photo oxidation of $\mathrm{SO}_{2}$ and components of the earth's crust $\mathrm{SiO}_{2}\left(1010,1032 \mathrm{~cm}^{-1}\right)$ [12]. These high 
values could be explained by the widely developed use of sulfur fuel (diesel) in buses and trucks, the combustion of which leads to the formation of carbonaceous soot rich in sulfur, especially in the environment highly polluted urban area [13].

The seasonal cycles of Ammonium in fine particles $\mathrm{PM}_{2.5}$, followed a pattern similar to that observed for the ions of the Sulfates with low rates in winter but probably strong in summer, which represents a favorable environment for the evaporation of this one [14]. This is because many absorption bands are likely to overlap. The nitrates $\left(\mathrm{NO}_{3}{ }^{-}\right)$, sulfates $\left(\mathrm{SO}_{4}{ }^{-2}\right)$ and ammonium $\left(\mathrm{NH}_{4}{ }^{+}\right)$ions which are very abundant in the aerosol produce very wide and intense absorption bands liable to interfere with the measurements of the desired chemical functions $[1,15]$. Nitrogen aerosols are reported to play an important role in deteriorating the air quality.

\subsection{Determination of Ammonium, Phosphates and Nitrates}

To identify the sources of $\mathrm{PM}_{2.5}$ emissions, we have analyzed ammonium $\mathrm{NH}_{4}{ }^{+}$, phosphates $\mathrm{PO}_{4}^{-3}$ and the nitrate $\mathrm{NO}_{3}{ }^{-}$by UV-Visible spectroscopy. The automatic classification of the mass concentrations found, appears 03 pollution classes.

\subsubsection{Pollution classes}

Table 1. Descriptive statistics of pollution classes by inorganic compounds (Ammonium, Nitrate and Phosphate)

\begin{tabular}{|c|c|c|c|c|c|c|c|c|}
\hline $\begin{array}{l}\text { Compounds }\left(\mathrm{ug} / \mathrm{m}^{3}\right) \\
\times 10^{-5}\end{array}$ & $\begin{array}{l}\text { Pollution } \\
\text { class }\end{array}$ & $E$ & $\mathbf{N}$ & Moy & Min & Max & Variance & $\begin{array}{l}\text { Standard } \\
\text { deviation }\end{array}$ \\
\hline Ammonium $\left(\mathrm{NH}_{4}\right)$ & 1 & 34 & 2 & 0,24 & 0,23 & 0,25 & 0,0002 & 0,014 \\
\hline Ammonium $\left(\mathrm{NH}_{4}\right)$ & 2 & 20 & 2 & 0,31 & 0,30 & 0,4 & 0,0032 & 0,057 \\
\hline Ammonium $\left(\mathrm{NH}_{4}\right)$ & 3 & 18 & 2 & 0,35 & 0,31 & 0,39 & 0,0032 & 0,057 \\
\hline Nitrate $\left(\mathrm{NO}_{3}{ }^{-}\right)$ & 1 & 34 & 2 & 0,23 & 0,22 & 0,24 & 0,0002 & 0,014 \\
\hline Nitrate $\left(\mathrm{NO}_{3}{ }^{-}\right)$ & 2 & 20 & 2 & 0,4 & 0,36 & 0,44 & 0,0032 & 0,057 \\
\hline Nitrate $\left(\mathrm{NO}_{3}{ }^{-}\right)$ & 3 & 18 & 2 & 0,81 & 0,66 & 0,95 & 0,0421 & 0,205 \\
\hline Phosphate $\left(\mathrm{PO}_{4}\right)$ & 1 & 34 & 2 & 0,022 & 0,018 & 0,027 & 0,0000 & 0,006 \\
\hline Phosphate $\left(\mathrm{PO}_{4}\right)$ & 2 & 20 & 2 & 0,038 & 0,028 & 0,049 & 0,0002 & 0,015 \\
\hline Phosphate $\left(\mathrm{PO}_{4}\right)$ & 3 & 18 & 2 & 0,067 & 0,054 & 0,080 & 0,0003 & 0,019 \\
\hline
\end{tabular}

E: number of samples involved in the class.

N: winter and summer period.

Table 1 clearly shows that the high concentrations of inorganic compounds were recorded in the third class with a maximum of $0.35 \pm 0.057 \mathrm{ug} / \mathrm{m} 3 \times 10-5,0.81 \pm 0.205 \mathrm{ug} / \mathrm{m} 3 \times 10-5$ and $0.067 \pm 0.019$ ug / m3 $\times 10-5$ in Ammonium, Nitrates and Phosphates respectively. These values are excessively higher than those for class 1 , which includes sites close to the drill. The second class characterizes urban sites.

Nitrates have the highest concentrations in all samples analyzed compared to phosphates which are slightly weak and superior to ammonium

These results are somewhat lower than the concentrations previously reported in the range of other studies [16-17] on the analysis of fine particles that are distributed from the atmospheric source to urban sites.

\subsubsection{Evolution of ions (Nitrates, Ammonium and Phosphates) during sampling}

We have performed an analysis of the variance between the analyzed ions and the sampling time, the result is shown in Fig. 6. 


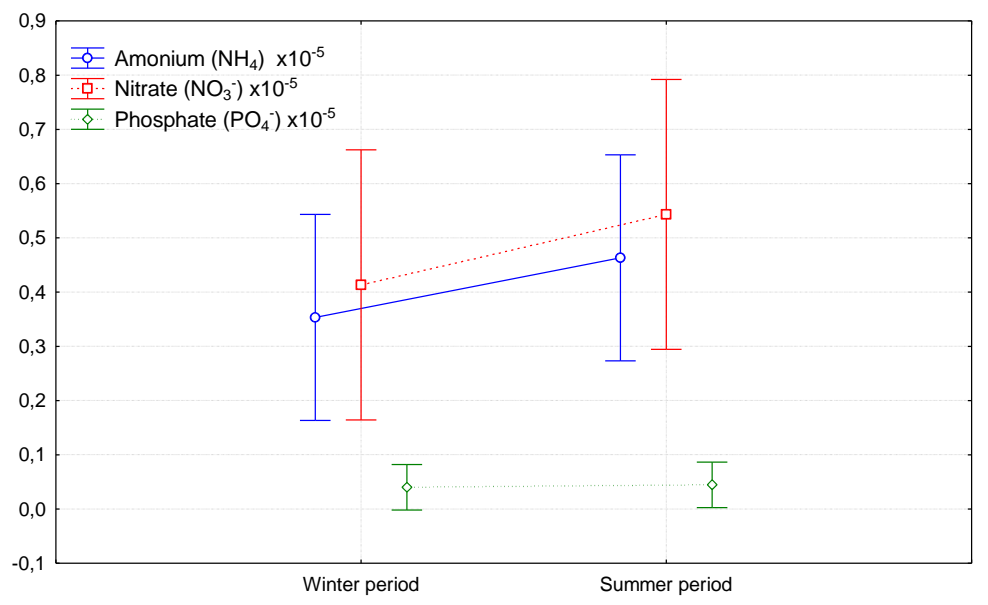

Fig. 6. Evolution of ions (Nitrate, Ammonium and Phosphate) during the sampling period

The examination of the Fig. 6 shows that the $\mathrm{NO} 3$ series had relatively lower winter levels, while $\mathrm{NH} 4+$ levels were slightly higher in summer-fall. These inverse seasonal trends are probably related to the summer oxidation conditions and the low thermal stability of $\mathrm{NH} 4 \mathrm{NO} 3$ during the warm period. In addition, $\mathrm{N}$ levels can also explain the high formation of nitrates in the winter period. In addition, $\mathrm{NH} 4+$ does not show a definite seasonal trend. Then, peaks of these elements occurred throughout the year and were strongly correlated with the appearance of Sahara dust reported during sampling.

$\mathrm{NH} 4+$ concentrations have been found to establish the charge compensation, or the neutralization, with NO3- and SO4-2 ions. This phenomenon could be partly explained on one hand by the relatively high emission rates of ammonium precursors in the sampling region, and on the other hand due to the instability of the ammonium salts in a particulate form. In relatively hot atmospheres, as was encountered during sampling campaigns. In this case, the neutralization of the NO3- and SO4-2 species could be explained by their association with $\mathrm{NH} 4+$, without excluding other transition metal ions [18]. The combination of these factors could explain the higher sulfate production and the volatilization of nitrate species in summer.

We find that fine, non-light absorbing inorganic aerosols such as sulfate can have a warming effect. Specifically, although the opacity of fine particles decreases at longer wavelengths, they can strongly absorb and re-emit the thermal radiation under resonant conditions at long wavelengths [19].

The higher levels of $\mathrm{NO}_{3}{ }^{-}$and $\mathrm{SO}_{4}{ }^{-2}$ in the urban site could be due to the presence of a very important source of $\mathrm{NOx}$ and $\mathrm{SO}_{2}$ which, by gas-particle conversion, are transformed into nitrate and sulfate ions respectively. The main sources of NOx in the urban site are combustion phenomena, in particular by the transport system, which is characterized by very dense traffic in the city agglomeration. As for $\mathrm{SO} 2$, the frequent use of sulfur fuels in heavy vehicles (buses and trucks) is the main source of $\mathrm{SO} 2$ in the urban site [20-21].

According to [22] Spring dust storms had a strong impact on the pm2.5 Overall, organic carbon was the most abundant species, accounting for at least $30 \%$ of the total mass of PM2.5, In these fine particles the ions: $\mathrm{Ca}+2$, SO4-2, NO3- are emitted by vehicles $[23,8] \mathrm{NH} 4+, \mathrm{K}$, by the diesel exhaust from buses. The presence of these elements with the $\mathrm{NH} 3$ therefore indicates that these particles are secondary aerosols. the nitrate is derived from gas-to-particle conversion processes by NOx oxidation products, which are mainly emitted in the vehicle exhaust gases.

\subsubsection{Correlation of PM 2.5 concentration and elements}

The examination of Fig. 7 shows that there is a highly significant deference between the three pollution classes $(p=0.00)$, with a dominance of $\mathrm{PM}_{2.5}$, recorded in the $3^{\text {rd }}$ class, which represents the schools located in the main streets of the city center, and exposed to heavy road traffic, coinciding with increased human activities in the city. 


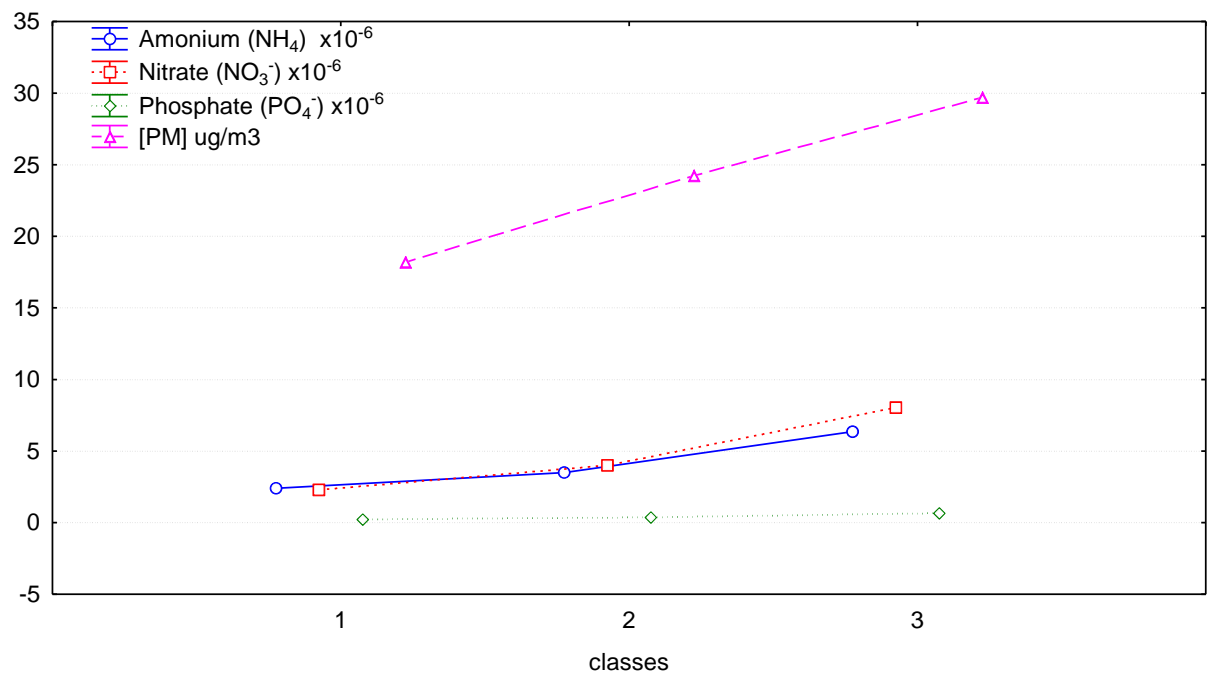
Fig. 7. Correlation analyzes between ammonium, nitrate, phosphate concentrations and mass
concentrations of $\mathrm{PM}_{2.5}$

The analysis in fig. 7 also shows that there is a positive correlation between the mass concentrations of $\mathrm{PM}_{2.5}$ and the inorganic elements analyzed (ammonium, nitrate and phosphate).

\subsection{Discussion}

In general, this study shows that non-destructive methods are effective in tracing the sources of $\mathrm{PM}_{2.5}$. They can be further improved and have a promising future in real-time $\mathrm{PM}_{2.5}$ monitoring. Thus, the generally anthropogenic spherical particles and those analyzed in this study exhibit a smooth surface and most of them are ammonium and nitrate which could come from the combustion of road traffic material [24]. On the other hand, given the fact that the particles emitted by road traffic can travel long distances up to $30 \mathrm{~km}$ before being deposited [25] these spherical particles could well be emitted in the main axes traffic in the city.

Sulfate and nitrate ions are the result of side reactions of aerosols, crustal dust with $\mathrm{HNO}_{3}$ and $\mathrm{H}_{2} \mathrm{SO}_{4}$. Sulfate is the result of high levels of $\mathrm{SO}_{2}$ from long distance transport; in winter [26, 27] corroborated by air mass during the same sampling days and by local exhaust emissions, thus diesel-powered buses run close to of sampling sites. Regarding the source of particulate nitrates, probably related to vehicle emissions. However, ammonia derived from vehicle emissions has recently attracted much attention [28-29]. The urban site is influenced by many direct and indirect sources of particulate emissions fines, such as the combustion of fuels which can be added to the resuspension of "soil dust" by the circulation of vehicles on the roads. All these factors can promote the formation of fine particles and could explain their higher concentrations in urban sites exposed to traffic compared to other sites.

The dominant species in urban areas are $\mathrm{NO}_{3}{ }^{-}, \mathrm{SO}_{4}{ }^{-2}$. They have a lower proportion (fewer local sources of $\mathrm{NO}_{3}^{-}$and $\mathrm{SO}_{4}^{-2}$ precursors) in sites close to forests. However, the same order of abundance of these ions exists in the two periods.

According to [22], Spring dust storms had a strong impact on $\mathrm{PM}_{2.5}$ overall, organic carbon was the most abundant species, accounting for at least $30 \%$ of the total mass of $\mathrm{PM}_{2.5}$, surtput in urban sites. In these fine particles, the ions: $\mathrm{Ca}_{2}{ }^{+}, \mathrm{SO}_{4}{ }^{-2}, \mathrm{NO}_{3}{ }^{-}$are emitted by vehicles $[30,22][31] \mathrm{NH}_{4}{ }^{+}, \mathrm{K}$, by diesel exhaust from buses. The presence of these elements with $\mathrm{NH}_{3}$ therefore indicates that these particles are secondary aerosols. Nitrate derives from gas-to-particle conversion processes by NOx oxidation products, which are mainly emitted in vehicle exhaust gases [31]. 


\section{SUSTAINABLE PLANNING AND INSTITUTIONAL DEVELOPMENT FOR COMBATING AIR POLLUTION}

In terms of urban atmospheric pollution, that generated by automobile traffic in toxic emissions of gases and particles, as well as the formation of carbon monoxide, partially oxidized compounds and sulfur or sulfur dioxide $\left(\mathrm{SO}_{2}\right.$ and $\left.\mathrm{SO}_{3}\right)$, which disperse, under the effect of the wind, in all directions and manifest itself as a difficulty in breathing, tingling of the throat and eyes and various irritations, high enough to cause adverse health effects, in susceptible individuals (children, elderly or sick).

The public authorities must, more particularly, ensure the adaptation and the strict application of the regulations in force. The fight to reduce toxic emissions in urban areas must also be the subject of the same rigor, given its effects on public health

\subsection{Nature Based Solution towards Sustainable Planning in Algeria}

The Algerian state must select alert thresholds for the danger of pollution to improve the air quality as well as atmospheric monitoring devices to assess the real degree of particulate pollution and implement a policy to protect human health. Pollution peaks and periods when thresholds are exceeded are detected and forecasts are made to plan and implement the measures necessary to improve air quality. Despite the difficulty of establishing environmental and energy strategies; Algeria, devotes specific provisions to the fight against the air pollution, by Law No. 43 of July 20, 2003, relating to the protection of the environment within the framework of sustainable development (www. Joradp. dz)

\subsection{Management and Sustainability Approaches to Combat $\mathbf{P M}_{2.5}$ Aerosols in Tiaret, Algeria}

Numerous scientific works have carried out by Algerian researchers confirm the need to reduce polluting emissions from road traffic by renewing the vehicle fleet, and improving the regulation of the engine combustion through the use of less polluting fuels.

The programs of the conservation of the vegetation cover and the planting of trees remain quite rational and reasonable, if one wants to rapidly increases the forest cover not only in the cities, but also in these schools, by favoring programs of the plantation of various types. This can include removing competing the vegetation, reducing the runoff, improving soil conditions, suppressing fires, and preparing the soil. However, it is recommended to:

- Rebuild forests and encourage the tree planting in new neighborhoods.

- Maintenance of the biological diversity and ecological balance;

- The use of bicycles instead of vehicles, minimizing the emission of the $\mathrm{PM}_{2.5}$

\subsection{Future Perspective}

This study is a first initiative to quantify and assess $\mathrm{PM}_{2.5}$ pollution in the Tiaret-city and give us a preliminary idea of the composition and sources of this pollution.

To manage the factors of the degradation of public health, it is recommended to carry out an epidemiological study to see the prevalence between the human exposure to fine particles and respiratory diseases.

- Enhancement of the city's air by creating the air quality monitoring stations, and ensuring citizen awareness campaigns

In our future work, we will aim to take the advantage of the easy and rapid nature of spectroscopic methods to chemically characterize the formation of primary and secondary aerosols, emitted by divergent sources such as the combustion of the biomass and vehicles during different episodes of pollution.

\section{CONCLUSION}


This study shows that non-destructive methods are effective in tracing the sources of $\mathrm{PM}_{2.5}$. They can still be improved and have a bright future in real-time $\mathrm{PM}_{2.5}$ monitoring.

The inorganic analysis had carried out by the FTiR-ATR spectroscopy, shows that the sulfate ions recorded their maximum in the summer period than in the winter, as well as the nitrate and ammonium ions which do not show a great seasonal deference.

The dominant species in urban areas are $\mathrm{NO}_{3}{ }^{-}, \mathrm{SO}_{4}{ }^{-2}$; However, the same order of abundance of these ions exists in the two sampling periods. The main source of NOx in the urban site is the phenomenon of the combustion linked to the transport which characterizes very dense traffic in the metropolitan area of the city.

These sites have been influenced by direct and indirect sources, such as the fuel combustion, which can add to the re-suspension of "soil dust" from vehicle traffic on the roads. All these factors promote the formation of fine particles and explain their abundance in urban sites exposed to the trafficking compared to sites close to forests.

The presence of $\mathrm{SiO}_{4}^{-2}$ and $\mathrm{CaCO}_{3}$ ions, in the sites which are in low places between the slopes, also showed that the dust storms are characterized by an enrichment in these elements, especially in winter season which has been characterized by the dominance of the sand wind by contribution to the summer season.

In conclusion, PM show significant variations in their chemical composition, linked in particular to the proximity of sources and to temporal variability (daily or seasonal), leading to a poor understanding of their effects on health. Indeed, the precise composition of the particulate aerosol, in particular its chemical composition, its evolution over time but also its concentration in the air remains difficult to understand.

\section{COMPETING INTERESTS}

Authors have declared that no competing interests exist.

\section{RÉFÉRENCE}

1. Samek L, Stegowski Z, Styszko K, et al. Seasonal variations of chemical composition of PM2.5 fraction in the urban area of Krakow, Poland: PMF source attribution; 2020.

2. $\mathrm{Xu}$ Yu, Wei Song, Qingqing Yu, et al. Fast screening compositions of PM2.5 by ATR-FTIR: Comparison with results from IC and OC/EC analyzers. Journal of environmental sciences. 2018;71:76- 88.

Available:https://doi.org/10.1016/j.jes.2017.11.021

3. STT: Service de transport de la wilaya de Tiaret ; 2018

4. Google earth V6.2.2.6613. (October 03, 2016) Tiaret City, Algeria. Dijital Globe; 2017. Available:http://www.earth.google.com [03/10/2016].

5. Cesari D, Donateo A, Conte M, et al. An inter-comparison of PM2.5 at urban and urban background sites: Chemical characterization and source apportionment. Atmos. Res. 2016;174-175;106-119. [CrossRef].

6. Madejová J. FTIR techniques in clay mineral studies. Vib. Spectrosc. 2003;31:1-10. [CrossRef]

7. Jiménez E, Linares C, Martínez D, et al. Role of Saharan dust in the relationship between particulate matter and short-term daily mortality among the elderly in Madrid (Spain). Sci. Total Environ. 408, 5729-5736. [CrossRef] [PubMed]; 2010.

8. Daniela V, Elisa T, Marcello V, Ida DC. ATR-FTIR Spectral Analysis and Soluble Components of PM10 And PM2.5 Particulate Matter over the Urban Area of Palermo (Italy) during Normal Days and Saharan Events; 2019.

9. Christelle Barbet. Modélisation régionale de la composition chimique des aérosols prélevés au puy de Dôme (France); 2015.

10. Cristina G, Alberto G, Frank dl; 2017: Air quality in Europe -2017 report; 2017. 
11. Hetem IG and Andrade MF. Characterization of Fine Particulate Matter Emitted from the Resuspension of Road and Pavement Dust in the Metropolitan Area of São Paulo, Brazil. Atmosphere. 2016;7:31.

12. Andrés $A$, Xavier $Q$, Feliciano $P$, et al. Identification and Chemical Characterization of Industrial Particulate Matter Sources in South west Spain; 2012.

Available:https://doi.org/10.1080/10473289.2006.10464502

13. Su-Ching K.a, Ying I.T.b, Cheng-Hsien T, et al. Carboxylic acids in PM2.5 over Pinus morrisonicola forest and related photoreaction mechanisms identified via Raman spectroscopy. doi:10.1016/ j.atmosenv.2011.08.007, Atmospheric Environment. 2011;45:6741e6750.

14. Jozef S, Pastuszka W, Rogula-Kozłowska et al; 2010: Characterization of PM10 and PM2.5 and associated heavy metals at the crossroads and urban background site in Zabrze, Upper Silesia, Poland, during the smog episodes. Environ Monit Assess. 2010;168:613-627.

DOI 10.1007/s10661-009-1138-8

15. Honglei Zhan, Kun Zhao, Rima Bao et al. Monitoring PM2.5 in the Atmosphere by Using Terahertz Time-Domain Spectroscopy. J Infrared Milli Terahz Waves. 2016;37:929-938. DOI 10.1007/s10762-016-0283-8

16. Turki MA. Habeebullah. Chemical Composition of Particulate Matters in Makkah - Focusing on Cations,Anions and Heavy Metals; 2015.

DOI: 10.4209/aaqr.2015.08.0486

17. Md Firoz K, SawWuan H, Lim Chee, et al. Influences of inorganic and polycyclic aromatic hydrocarbonson the sources of PM2.5 in the Southeast Asian urban sites Air Qual, Atmos Health. 2017;10:999-1013.

DOI 10.1007/s11869-017-0489-5

18. Arruti A, Fernández-Olmo I, Irabien A. Regional evaluation of particulate matter composition in an Atlantic coastal area (Cantabria region, northern Spain): Spatial variations in different urban and rural environments. Atmospheric Research. 2011;101:280-293.

19. Shau-Liang C , Sih-Wei C, Yen-Jen C, Hsuen-Li C. Possible warming effect of fine particulate matter in the atmosphere; 2021.

20. Pulles $\mathrm{T}$, et al. Emission factors for heavy metals from diesel and petrol used in European vehicles. Atmospheric Environment. 2012;61:641-651.

21. Omar $Y$, M'hamed $M$, Nadera $A$, et al. Bioaccumulation de la pollution plombique d'origine routiere au moyen d'une mousse (bryum argenteum) dans la ville de tiaret (Algérie): classes de pollution et cartographie. European Scientific Journal, ESJ. 2015;11(8).

22. Dinh TT. Identification des sources et modélisation du comportement dynamique des particules dans l'air intérieur des écoles; 2011.

23. Gu J, Bai Z, Li W, Wu L, Liu A, Dong H, Xie Y. Chemical composition of PM2. 5 during winter in Tianjin, China. Particuology. 2011;9(3):215-21

24. Irene R.g, Salvador G, Celia M. Atmospheric inorganic aerosol of a non-industrial city in the centre of an industrial region of the North of Spain, and its possible influence on the climate on a regional scale. Environ Geol. 2009;56:1551-1561.

DOI 10.1007/s00254-008-1253-9

25. Querol X, Viana M, Alastuey A, et al. Source origin of trace elements in PM from regional background, urban and industrial sites of Spain". 4172197231 Atmospheric Environment; 2007.

26. Lutz. M, Bruckmann P, et al. Speciation and origin of PM10 and PM2.5 in selected European cities. Atmos. Environ. 2004;38:6547-6555.

27. Stone EA, et al. Composition of Fine and Coarse Particulate Matter in Gosan, Korea during the Springtime Dust Season. Aerosol Air Qual. Res. 2011;11:31-43.

28. Liu TY, Wang XM, Deng W, et al. Role of ammonia in forming secondary aerosols from gasoline vehicle exhaust. Sci. China Chem. 2015;58:1377-1384.

29. Chang Y.H, Liu X.J, Deng C.R et al. Source apportionment of atmospheric ammonia before, during, and after the 2014 APEC summit in Beijing using stable nitrogen isotope signatures. Atmos. Chem. Phys. 2016;16:11635-11647.

30. Wittig AE, Takahama S, Khlystov AY, Pandis SN, Hering S, Kirby B, Davidson C. Semicontinuous PM2. 5 inorganic composition measurements during the Pittsburgh Air Quality Study. Atmospheric Environment. 2004;38(20):3201-13.

31. Carrier M. La distribution des polluants atmosphériques et du bruit provenant du transport routier dans les milieux résidentiels de l'île de Montréal: un cas d'équité environnementale 
(Doctoral dissertation, Université du Québec, Institut national de la recherche scientifique) ; 2015.

32. Bell ML, Ebisu K, Leaderer BP, et al. Associations of PM2. 5 constituents and sources with hospital admissions: analysis of four counties in Connecticut and Massachusetts (USA) for persons $>$ or $=65$ years of age. Environ. Health Perspect. 2014;122(2):138.

33. Chalvatzaki E, Chatoutsidou SE, Lehtomaki H, et al. Characterization of human health risks from particulate air pollution in selected European cities. Atmosphere. 2019;10(2):96. Available:https://doi.org/10.3390/ atmos10020096

34. Falkovich A. H, Ganor E, Levin Z, et al. Chemical and mineralogical analysis of individual mineral dust particles, J. Geophys. Res. 2001;106(18):029-18 036.

35. Gass K, Balachandran S, Chang $\mathrm{HH}$, et al. Ensemblebased source apportionment of fine particulate matter and emergency department visits for pediatric asthma. Am. J. Epidemiol. 2015;181(7):504-512.

36. Ito K, Christensen WF, Eatough DJ, et al. PM source apportionment and health effects: 2. An investigation of intermethod variability in associations between source-apportioned fine particle mass and daily mortality in Washington, DC. J. Expo. Sci. Environ. Epidemiol. 2006;16 (4):300.

37. Kocak M, Kubilay N, Mihalopoulos N. lonic composition of lower tropospheric aerosols at a Northeastern Mediterranean site: implications regarding sources and long-range transport, Atmos. Environ. 2004;38:2067-2077.

38. Krall JR, Mulholland JA, Russell AG, et al. Associations between sourcespecific fine particulate matter and emergency department visits for respiratory disease in four US cities. Environ. Health Perspect. 2016;125(1):97-103.

39. Krzyżanowski M, Kuna-Dibbert B, Schneider J. Health effects of transport related air pollution; 2005.

40. Mengjiao $\mathrm{H}$, Cesunica I, Yongtao $\mathrm{H}$, et al. Source apportionment of primary and secondary PM2.5: Associations with pediatric respiratory disease emergency department visits in the U.S. State of Georgia. Environment International. 2019;133:105167.

Available: https://doi.org/10.1016/j.envint.2019.105167.

41. Moreno T, Querol X, Alastuey A, et al. Airborne particulate matter and premature deaths in urban Europe: The new WHO guidelines and challenge ahead as illustrated by Spain. European Journal of Epidemiology. 2007;22:1-5.

42. Ostro B, Malig B, Hasheminassab S, et al. Associations of source-specific fine particulate matter with emergency department visits in California. Am. J. Epidemiol. 2016;184(6):450-459. 


\section{Biography of author(s)}

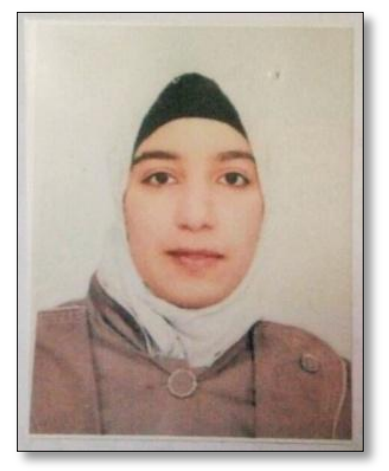

\section{Dr. Naceur Khadidja}

Laboratory of Agro-biotechnology and Nutrition in Semi-arid Areas. Faculty of Natural Sciences and Life, University of Tiaret, Tiaret BP 78 Zaaroura, Tiaret, Algeria.

Research and Academic Experience: She Doctorate in Ecology and Environment, which specialized at Ecology and preservation of terrestrial ecosystems in December 2019. She has done Diploma of Higher Studies, in Biochemistry, June 2012 and Master's degree in Pathology of Ecosystems, June 2016 respectively.

She has obtained an Online training: CUPAGIS Online Master Classes, from TU Berlin, Germany from Nov 2020 to June 2021. Research Area: Her research interest are in the field of Ecology and preservation of ecosystems Water, soil and air analyzes, Essential oils, Spectroscopie Raman, and Gas chromatography-mass spectrometry.

Number of Published papers: She has Five published papers which listed in Scopus.

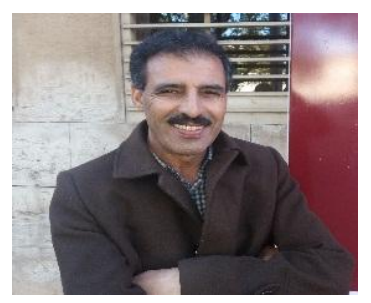

Prof. Maatoug Mohamed

Laboratory of Agro-biotechnology and Nutrition in Semi-arid Areas. Faculty of Natural Sciences and Life, University of Tiaret, Tiaret BP 78 Zaaroura, Tiaret, Algeria.

Research and Academic Experience:

$\mathrm{He}$ is a Professor in land ecosystem management since 2009

ORCID : 0000-0001-5620-0931

Scopus Author ID: 57192573890 .

Researcher ID: T-6939-2018

Number of Published papers: He has 45 published articles and chapters Book which listed in Scopus. He directed more than 25 doctoral theses

Any other remarkable point(s): He Participated in several research projects on agroecology, sustainable water management and depollution and fertilization of agricultural soils by biological means and Participated in numerous international research projects. 


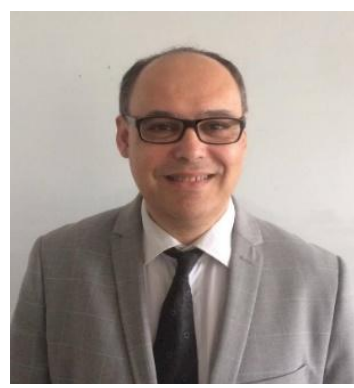

Serge Bresson

Institut Polytechnique UniLaSalle, Universite d'Artois, ULR 7519, 19 Rue Pierre Waguet, BP 30313, 60026 Beauvais, France

Research and Academic Experience: He teaches at Université Picardie Jules Verne, Amiens, FRANCE

Research Area: His research interest includes at Physico-chemical characterization of materials by IR and Raman spectroscopies, XRD, DSC, mass spectrometer

Number of Published papers: He has 54 Published papers

Special Award: He got awarded to Who's Who In Science and Engineering 2003-2006

(C) Copyright (2021): Author(s). The licensee is the publisher (B P International). 